\title{
TARGETING OF THE PRO-OXIDANT-ANTIOXIDANT BALANCE IN VITRO AND IN VIVO BY 4-THIAZOLIDINONE-BASED CHEMOTHERAPEUTICS WITH ANTICANCER POTENTIAL
}

\author{
L. KOBYLINSKA ${ }^{1 \bowtie}$, O. KLYUCHIVSKA ${ }^{2}$, R. LESYK ${ }^{1}$, R. STOIKA ${ }^{2}$ \\ ${ }^{1}$ Danylo Halytsky Lviv National Medical University, Ukraine; \\ ${ }^{2}$ Institute of Cell Biology, Lviv, Ukraine; \\ 凶e-mail: lesya8@gmail.com
}

Received: 05 January 2019; Accepted: 20 March 2019

Oxidative stress is one of the main mechanisms by which anticancer chemotherapeutics damage normal tissues and organs. At the same time, it is an important biochemical mechanism of the neoplastic action of such medicines. The aim of the present study was to determine the pro-oxidant-antioxidant balance in vitro and in vivo under the influence of novel 4-thiazolidinone-based chemotherapeutics with anticancer potential. An advantage of using these compounds in vivo is their low general toxicity, compared to doxorubicin (Kobylinska L. et al., 2014, 2015, 2016). The 4-thiazolidinone derivatives (Les-3288, Les-3833, Les-3882) with previously established anti-neoplastic activity in vitro (Kobylinska L. et al., 2016) and antitumor effect in vivo (Kobylinska L. et al., 2018) were synthesized, dissolved in dimethyl sulfoxide, and administered intraperitoneally to Wistar rats daily for 20 days. Doses of the injected drugs equaled $10 \%$ of the $L D_{50}$, namely doxorubicin - $5.5 \mathrm{mg} / \mathrm{kg}$, Les-3882 and Les-3833 - $10.7 \mathrm{mg} / \mathrm{kg}$, and Les-3288 - $24.3 \mathrm{mg} / \mathrm{kg}$. The radical scavenging of 1,1-diphenyl-2-picrylhydrazil (DPPH) activity was measured. Concentrations of thio-barbituric acid-active products were assessed in blood serum, liver, heart and kidney tissues of treated rats. Additionally, the activities of superoxide dismutase, catalase and glutathione peroxidase were measured in blood serum and these tissues. We found that administration for 20 days of Les-3288, Les-3833 and Les-3882 compounds disturbed the pro-oxidant-antioxidant balance in the treated rats. Increased amounts of products of reactions of lipid peroxidation and exhaustion of the enzymatic antioxidant system in liver, heart and kidney tissues were detected. In general, Les-3288, Les-3833 and Les-3882 compounds exhibited less pro-oxidant action, compared with the effect of doxorubicin. According to the results of influencing the pro-oxidant-antioxidant balance in the selected tissues, the studied compounds can be ranked in the following order: doxorubicin $>>$ Les-3833 $>$ Les-3288 >> Les-3882. The results of measuring direct scavenging ability of these compounds observed in $24 \mathrm{~h}$ suggests their lower toxic effect compared with the effect of the doxorubicin. The obtained results are in correspondence with the results of our recent experiments demonstrating their antineoplastic effect in vitro (Kobylinska L. et al., 2016) and anticancer action in vivo (Kobylinska L. et al., 2018), as well as their lower general toxicity in vivo compared with doxorubicin (Kobylinska L. et al., 2014, 2015, 2016).

Keywords: 4-thiazolidinone derivatives, doxorubicin, products of lipid peroxidation, enzymes of antioxidant defense, pro-oxidant-antioxidant balance.

$\mathrm{T}$ he reactive oxygen species (ROS) are primary inducers of apoptosis that are switched on by chemotherapeutic drugs in tumor cells [1-3]. However, neither the augmentation nor reduction of the amount of ROS can guarantee a positive therapeutic effect of an applied antitumor drug. ROS possess dual functions based on antagonism in the action of their different types and the activity of different systems of enzymatic and non-enzymatic antioxidant defenses. At a low level, ROS can activate signaling mechanisms that promote cell proliferation, whereas an excess of ROS irreversibly affects

(C) 2019 Kobylinska L. et al. This is an open-access article distributed under the terms of the Creative Commons Attribution License, which permits unrestricted use, distribution, and reproduction in any medium, provided the original author and source are credited. 
the molecular components of a cell and leads to its death [4]. A balance between the production and neutralization of ROS provides a pro-oxidant-antioxidant balance or redox homeostasis in the cell $[5,6]$. An increase in the ROS level destroys tumor cells, and, in general, these cells are considered more vulnerable to a disturbance of the oxidative-reductive processes and mitochondrial functions than normal cells. Consequently, an imbalance in the ROS and redox homeostasis in cancer cells plays a key role in anticancer chemotherapy [6]. A direct influence of ROS on processes associated with apoptosis positively correlates with their overall toxic effect on cellular structures, in particular, an impairment of the mitochondrial respiratory chain $[2,7]$.

ROS participate in the oxidative stress caused by anticancer drugs [4]. They can cause the severe side effects induced by these drugs, as well as the side effects of non-steroidal anti-inflammatory drugs, anti-retroviral drugs, analgesics, and other medicines. [3]. The oxidative stress-related cardiotoxicity mechanisms of doxorubicin (Dox) action are well known, and they include formation of free radicals, lipid peroxidation, mitochondrial dysfunction, impairment of calcium signaling, DNA damage, and activation of apoptotic signaling [2]. Free radicals induced by oxidative stress can also lead to energy imbalance, whereas an inhibition of Dox-induced ROS production significantly inhibits the abovementioned toxic effects of this anticancer drug [3].

The anticancer drugs used in chemotherapy cause an excessive activation of lipid peroxidation (LPO) in biomembranes and shift the redox balance [8]. Cell damage induced by peroxides can be prevented by the antioxidant system (AOS) that regulates the LPO response in membranes and controls the content of ROS and free radicals, by using both enzymatic and non-enzymatic mechanisms [8]. The AOS not only deactivates the ROS and peroxides, but also keeps an optimal concentration of free radicals and a stationary level of LPO [9-11]. The mobilization of the antioxidant activity (AOA) is an important mechanism in the adaptation process, although its effectiveness is not always sufficient to regulate activated LPO and counteract peroxide-induced tissue damage [6, 9].

The liver, heart and kidney tissues of rats are good objects for studying the in vivo toxicity of anticancer agents [12]. In liver tissue, the main reactions occur for neutralizing xenobiotics, in particular the anticancer drugs, while in kidney tissue the products of drug metabolism can be found. Assessing the toxic effect on heart tissue caused by chemotherapeutic agents is informative, since most of these agents possess cardiotoxicity. Thus, although liver, heart and kidney tissues participate in drug metabolism, they differ in the type of metabolic processes according to their individual functions.

Presently, chemotherapy is the main approach in the treatment of cancer patients. Therefore, there is a perpetual need to develop various anticancer agents that possess high treatment efficacy and minimal side effects [13]. Synthetic heterocyclic 4-thiazolidinone derivatives have demonstrated high antineoplastic potential in vitro within the framework of the Developmental Therapeutic Program for new antitumor compounds at the National Cancer Institute (Bethesda, Maryland, USA) [14-17]. As a result of such studies, the pyrazoline-thiazolidinone-isatin derivatives Les-3288, Les-3833 and Les-3882 were selected as the most promising candidates for further preclinical studies [18].

The aim of this study was to determine the effects of the 4-thiazolidinone-based potential anticancer chemotherapeutics - Les-3288, Les-3833, Les-3882 - on the indicators of the pro-oxidantantioxidant balance in the liver, heart and kidneys of laboratory rats. We hypothesized that these compounds differentially affect the balance of the products of LPO and the activity of enzymes of the antioxidant defenses in the targeted organs. The direct scavenging ability of these compounds towards a reduced glutathione observed in $24 \mathrm{~h}$ was also measured.

\section{Materials and Methods}

Drugs. The heterocyclic 4-thiazolidinonebased chemotherapeutics (compounds Les-3288, Les-3833 and Les-3882) were synthesized as described previously [19]. Dox was purchased from a Pfizer (Milano MI, Italy) representative in Ukraine.

Animals. All experiments using experimental rats were conducted under the control of the Bio-Ethics Commission at Danylo Halytsky Lviv National Medical University (Protocol N4 dated by April 18, 2016) in Lviv, Ukraine. Mature white Wistar laboratory rats (200-220 g) were kept on standard fodder in the animal facility with adequate lighting and temperature conditions [12].

All compounds under study were administered to rats intraperitoneally every day in the morning before the first meal. Rats had 24-hour access to wa- 
ter. This procedure for drug administration is common in a pre-clinical study of medicines [12]. The experiment lasted for 20 days. Dox was injected at initial doses of $5.5 \mathrm{mg} / \mathrm{kg}$ for Les-3833, $10.7 \mathrm{mg} / \mathrm{kg}$ for Les-3882 and $24.3 \mathrm{mg} / \mathrm{kg}$ for Les-3288. The dose was gradually increased by 1.5 times during 4 days in order to achieve a cumulative effect. The starting dose equaled $10 \%$ of the maximum injected dose calculated in experiments that determined the $\mathrm{LC}_{50}$ [12]. The rats were euthanized on the $20^{\text {th }}$ day by decapitation under thiopental anesthesia. Serum was obtained from blood samples. After taking organs from each animal the tissue samples were homogenized in phosphate buffer $\mathrm{pH} 6.01: 4$, centrifuged at $5000 \mathrm{rpm}$ and supernatant was used to determine of biochemical parameters.

Assay for scavenging activity. Radical scavenging activity of 1,1-diphenyl-2-picrylhydrazil (DPPH) was measured, as described by Asatiani et al. [20]. A solution of $0.1 \mathrm{mM}$ DPPH was prepared and $1 \mathrm{ml}$ of this solution was added to $3 \mathrm{ml}$ of solutions of the investigated drugs in concentrations $1 \mu \mathrm{g} / \mathrm{ml}$. DMSO was used as a solvent. The reaction mixture was vortex-mixed at room temperature, and the absorbance was determined at 20 min after mixing and at $24 \mathrm{~h}$ by measurement at $520 \mathrm{~nm}$ with a multifunctional reader Infinite M1000PRO (Tecan, Switzerland). A decrease in absorbance of the resulting solution was then measured spectrophotometrically at $520 \mathrm{~nm}$. All experiments were repeated three times with three parallels in each variant. Inhibition (\%) of DPPH free radicals was calculated as follows: $\left.\left[\left(A_{0}-A_{1}\right)\right] / A_{0}\right] \times 100 \%$, where $A_{0}$ is the absorbance of the control and $A_{1}$ is the absorbance of the sample.

Measurement of TBA-active products. For measuring the amount of malonic dialdehyde, $0.5 \mathrm{ml}$ of a $1 \%$ solution of thiobarbituric acid (TBA) in $50 \mathrm{mM} \mathrm{NaOH}$ and $0.5 \mathrm{ml}$ of a $2.8 \%$ solution of trichloroacetic acid were added to aliquots of tissue homogenates. The mixture was kept for $20 \mathrm{~min}$ in a boiling water bath, cooled to room temperature, and then the optical density was read at $532 \mathrm{~nm}$ [21]. The concentrations of the TBA-active products were presented as $\mu \mathrm{mol} / \mathrm{mg}$ of protein.

The activity of superoxide dismutase (SOD, EC 1.15.1.1) was measured in the reduction reaction of nitrotetrazolium blue to nitroformazan. The assay medium contained $0.1 \mathrm{ml}$ of blood serum or a homogenate sample (1:10 dilution), $0.9 \mathrm{ml}$ of distilled water, $0.5 \mathrm{ml}$ of absolute ethyl alcohol, $0.25 \mathrm{ml}$ of chloroform and $0.3 \mathrm{~g}$ of $\mathrm{KH}_{2} \mathrm{PO}_{4}$. The mixture was shaken vigorously, centrifuged (5,000 rpm, $30 \mathrm{~min}$ ), and then $0.1 \mathrm{ml}$ of NADPH and $0.05 \mathrm{ml}$ of the incubation solution (37 mg EDTA, 330 mg p-iodonitrotetrazolium violet, $55 \mathrm{mg}$ phenazine methosulfate) were added to the supernatant and incubated for $10 \mathrm{~min}$ at $20^{\circ} \mathrm{C}$. The absorbance was read immediately at $540 \mathrm{~nm}$. SOD activity was presented as $\mu \mathrm{mol} / \mathrm{min}$ per $\mathrm{ml}$ or $\mathrm{mg}$ of protein [22].

The activity of catalase (CAT, EC 1.11.1.6) was determined by measuring a decrease in the hydrogen peroxide $\left(\mathrm{H}_{2} \mathrm{O}_{2}\right)$ concentration at $410 \mathrm{~nm}$. The assay medium consisted of $1 \mathrm{ml}$ Tris- $\mathrm{HCl}$ buffer solution (0.05 mmol, $\mathrm{pH} 7.8), 0.1 \mathrm{ml}$ of blood serum or homogenate sample and $2 \mathrm{ml}$ of $0.03 \% \mathrm{H}_{2} \mathrm{O}_{2}$. The reaction was stopped after 10 min of incubation by adding $1 \mathrm{ml}$ of $4 \%$ ammonium molybdate. The measurement was conducted at $410 \mathrm{~nm}$, and the activity of CAT of blood serum was presented as micromoles of $\mathrm{H}_{2} \mathrm{O}_{2} /$ min per $\mathrm{ml}$ or per $\mathrm{mg}$ of protein [23].

The activity of glutathione peroxidase (GPO, EC 1.11.1.9) was measured at $262 \mathrm{~nm}$, as the quantity of reduced glutathione. It was presented as micromoles of reduced glutathione per $1 \mathrm{~min}$ in $1 \mathrm{ml}$ for blood serum and in $1 \mathrm{mg}$ of protein for tissues [24].

We also calculated the oxidative stress index (OSI): $\mathrm{LPO} / \mathrm{SOD}+\mathrm{CAT}+\mathrm{GPO}$ ratio, as reported by Ruas et al. [25].

Data analysis and statistics. The results were analyzed using GraphPad Prism 7 (GraphPad Software, Inc, San Diego, CA, USA). Statistical analysis was performed using a $t$-test or two-way analysis of variance (ANOVA) for comparison of groups. All data are presented as the mean $\pm \mathrm{SD}$. $\mathrm{P}$ values less than 0.05 were considered statistically significant and marked with asterisks: $* P<0.05$; *** $P<0.01$.

\section{Results and Discussion}

The content of TBA-active products is considered to be an integrated indicator of the activity of the reactions of LPO induced under the action of various toxic agents [8]. Here we demonstrated a similar pattern of content of LPO products in three organs - liver, heart and kidney of rats treated with each of the three 4-thiazolidinone-based derivatives, with Dox used as a positive control. In liver, Dox increased by $58 \%$ the content of TBA-active products (Fig. 1). The same tendency was detected in the liver of rats treated with Les-3833, but the increase in content of TBA-active products was lower 
at $44 \%$ (Fig. 1). In heart tissue of rats treated for 20 days with Les-3833, the content of these products increased by $94 \%$ (Fig. 1). A 20-day administration of Les-3833 increased by 77\% the content of the LPO products in kidney tissue of the treated rats. The effects of Les-3288 and Les-3882 on the content of TBA-active products in liver, heart and kidney tissues were significantly less than those of Dox. For example, the content of LPO products after 20 days of Les-3882 administration was increased by $52 \%$ in heart tissue and after of Les-3288 administration by $40 \%$ in kidney tissue (Fig. 1).

Next, we measured the activities of the enzymes of the antioxidant defense system - SOD, CAT and GPO - in liver, heart and kidney homogenates of the experimental rats treated with different 4-thiazolidinone-based derivatives, with Dox used as a positive control. Dox administration decreased SOD activities in homogenates of all organs under investigation: by $42 \%$ - in liver, $41 \%$ - in heart, and $35 \%$ - in kidney (Fig. 2). These effects could be explained by the action of free radicals induced by Dox, because the cardiotoxic effect of Dox is based on the increased generation of the superoxide anion radical in mitochondria. In contrast, after 20 days of administration, Les-3288 decreased SOD activity by $23 \%$ in heart tissue and 27\% in kidney tissue (Fig. 2). An injection of Les-3833 decreased SOD activity by $26 \%$ in rat liver, by $48 \%$ - in rat heart, and by $42 \%$ in rat kidney (Fig. 2). A 20-day administration of Les-3882 decreased SOD activity by $75 \%$ only in kidney tissue, while in heart tissue, this compound slightly increased the activity of SOD (Fig. 2).

Administration of Dox led to a decrease in CAT activity in homogenates of all investigated organs of rats (Fig. 3). Whereas the effect of 20 days of administration of Les-3288 was characterized by an increase of CAT activity by $27 \%$ in liver, by $52 \%$ - in kidney, and by $43 \%$ - in heart (Fig. 3). Les3833 caused an increase of CAT activity by $20 \%$ in liver and by $28 \%$ - in heart (Fig. 3). After 20 days of administration, the Les-3882 compound acted differentially on CAT activity by decreasing it by $28 \%$ in heart and kidney, but by increasing it by $15 \%$ in liver (Fig. 3).

The activity of the antioxidant enzyme GPO was decreased under the action of all agents under study (Fig. 4). Dox reduced the GPO activity by $34 \%$

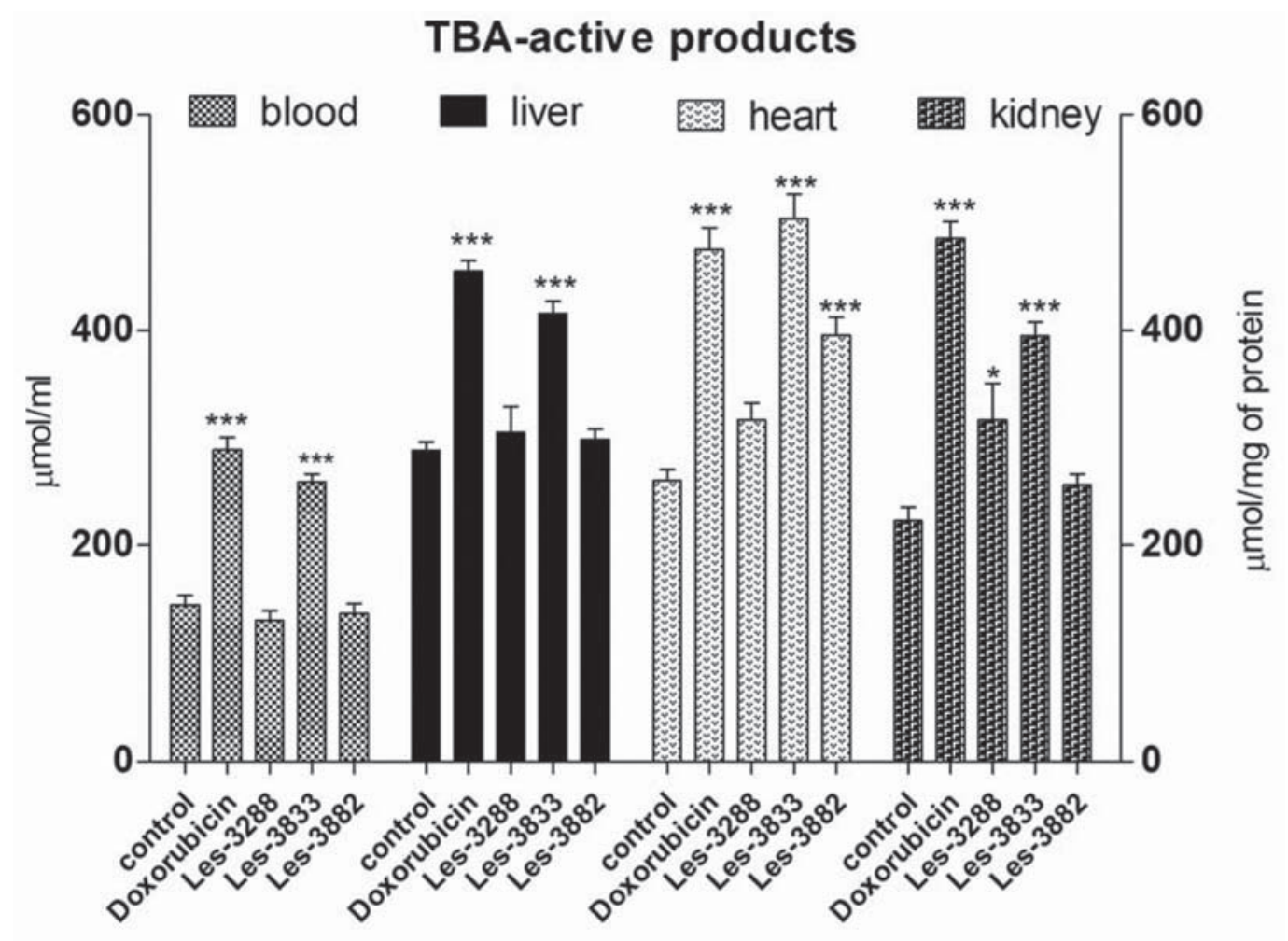

Fig. 1. Concentrations of TBA-active products in blood serum, liver, heart and kidney of rats treated with doxorubicin and Les-3288, Les-3833 and Les-3882. $* P \leq 0.05 ; * * * P \leq 0.01$ (difference compared to control). TBA, thiobarbituric acid 


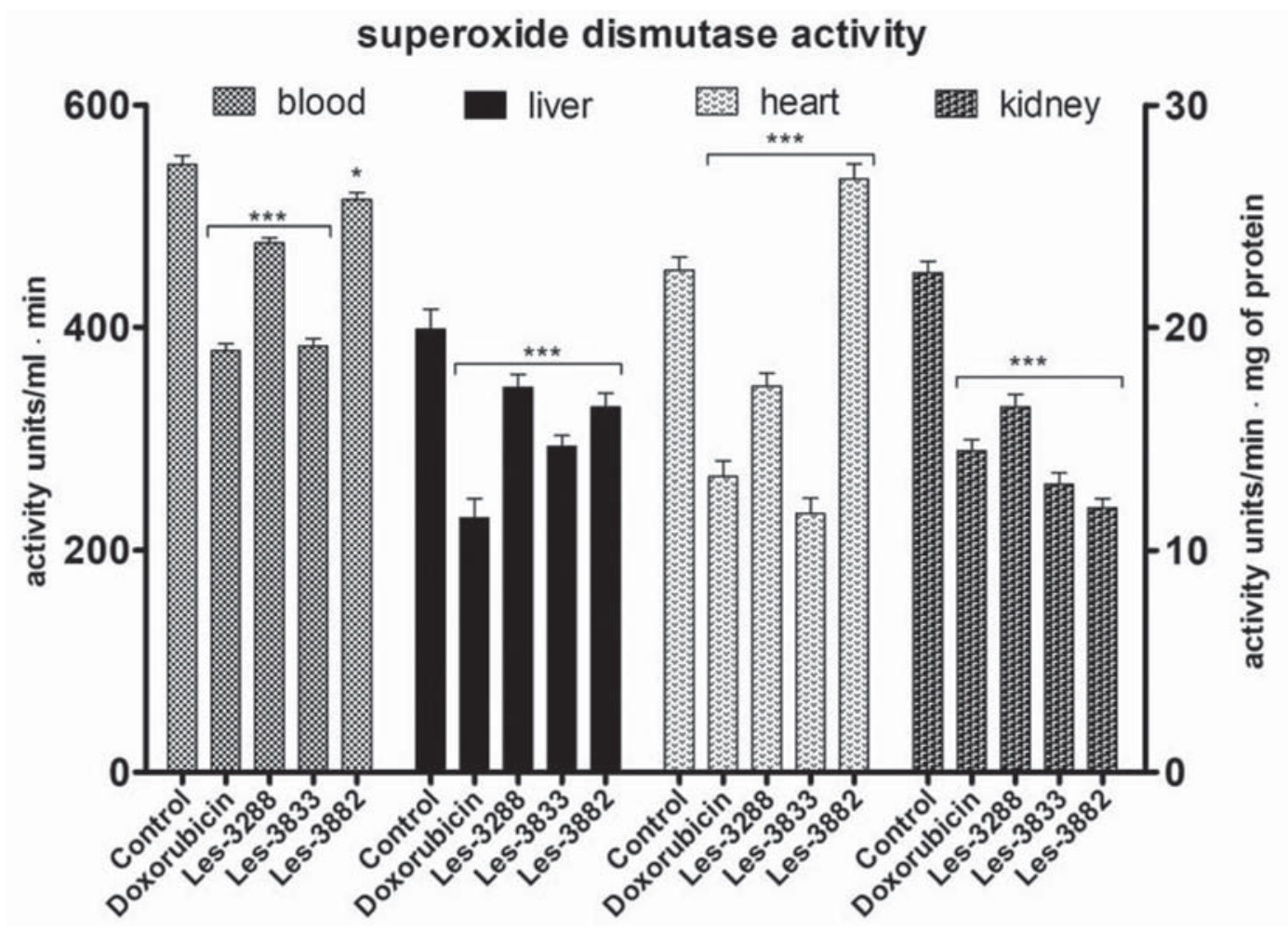

Fig. 2. Superoxide dismutase (SOD) activity in blood serum, liver, heart and kidney of rats treated with doxorubicin and Les-3288, Les-3833 and Les-3882. *P $\leq 0.05 ; * * P \leq 0.01$ (difference compared to control)

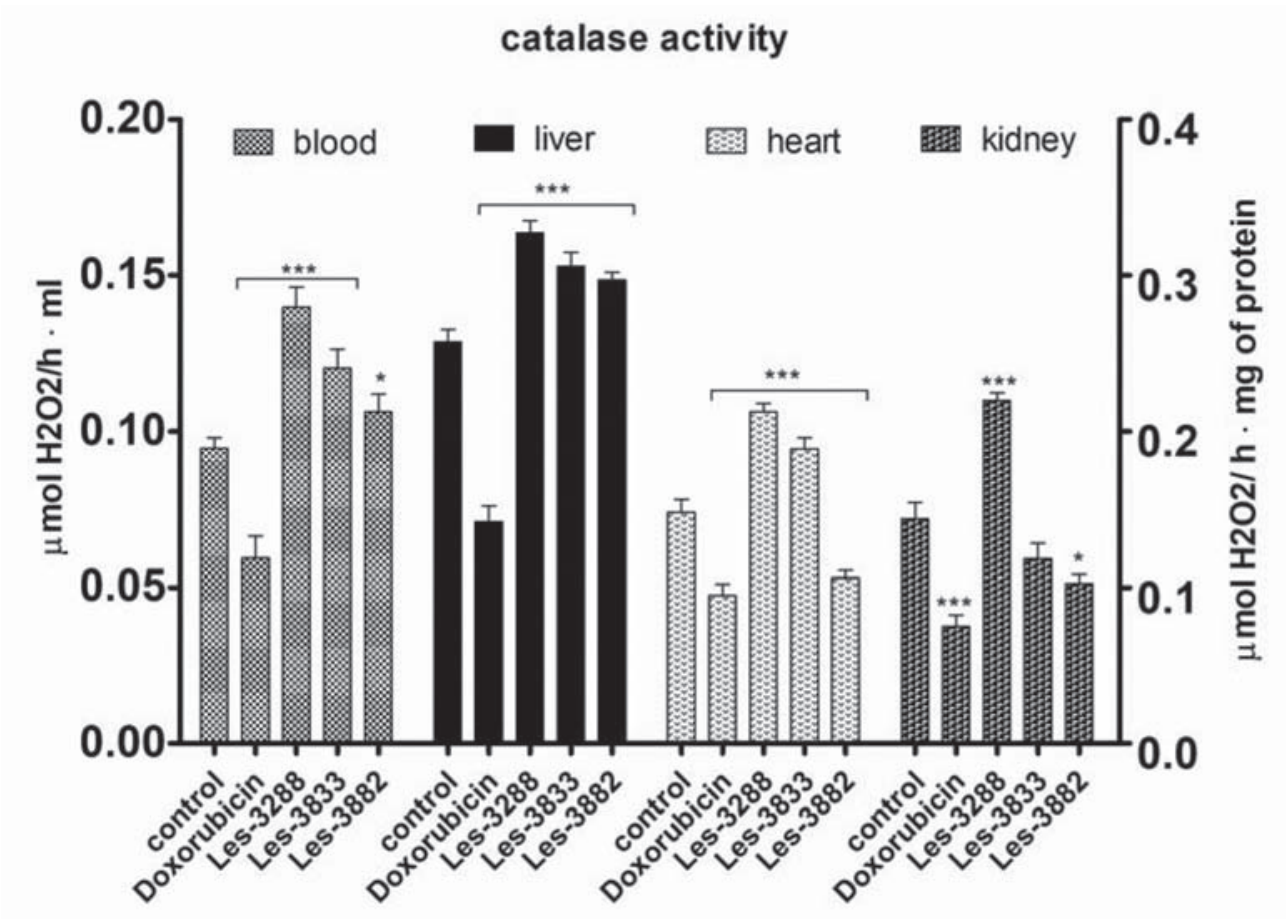

Fig. 3. Catalase (CAT) activity in blood serum, liver, heart and kidney of rats treated with doxorubicin and Les-3288, Les-3833 and Les-3882. $* P \leq 0.05 ; * * * P \leq 0.01$ (difference compared to control) 


\section{glutathione peroxidase activity}

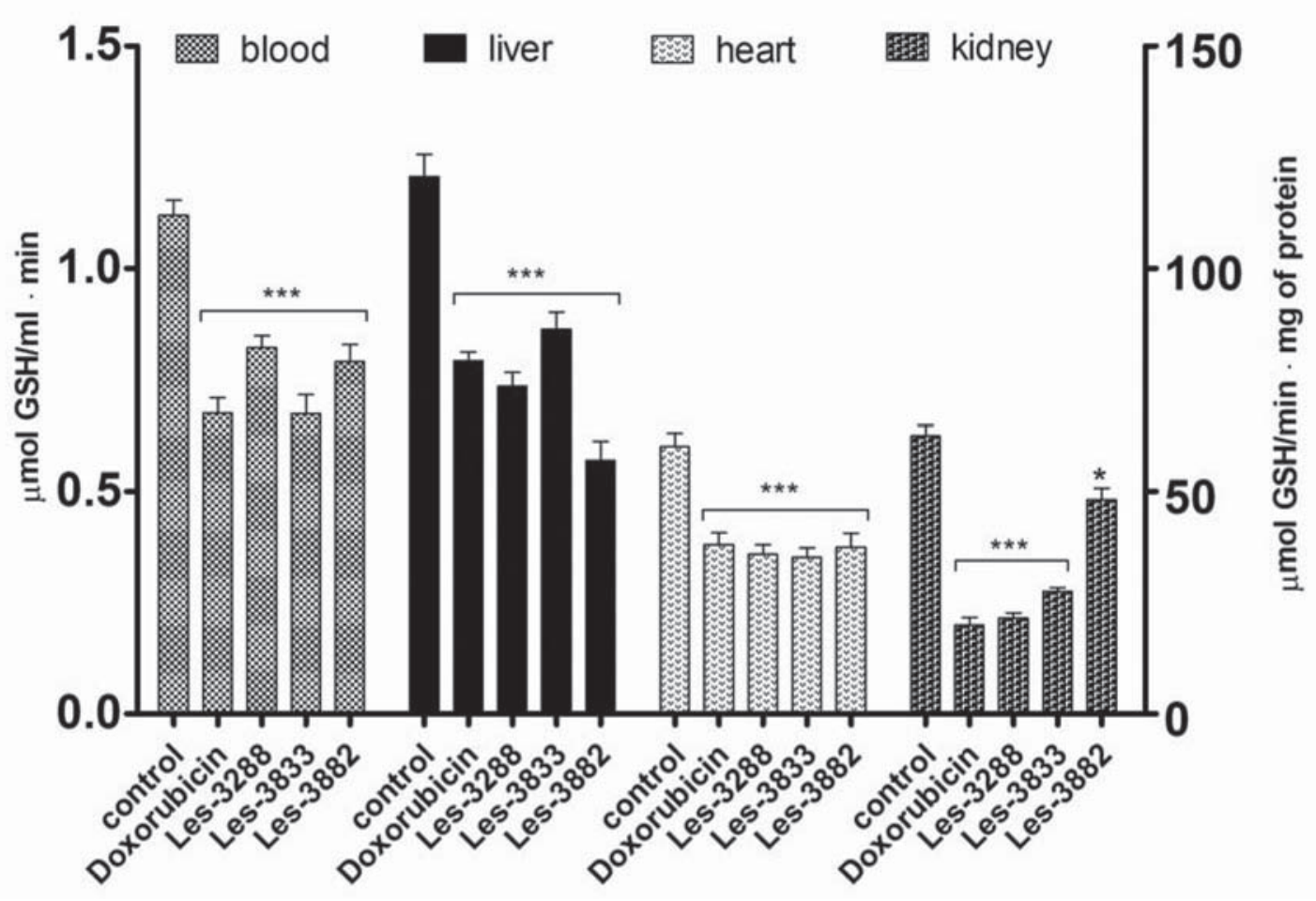

Fig. 4. Glutathione peroxidase (GPO) activity in blood serum, liver, heart and kidney of rats treated with doxorubicin and Les-3288, Les-3833 and Les-3882. ${ }^{*} P \leq 0.05 ; * * * P \leq 0.01$ (difference compared to control)

in liver, by $36 \%$ - in heart, and by $68 \%$ - in kidney (Fig. 4). After 20 days of administration, Les-3288 reduced the GPO activity by $39 \%$ in liver, by $41 \%$ in heart, and by $65.5 \%$ - in kidney (Fig. 4). After 20 days of administration, Les-3833 decreased the activity of GPO by $28 \%$ in liver, by $41 \%$ - in heart, and by $56 \%$ - in kidney (Fig. 4). The Les-3882 compound had an inhibitory effect toward the activity of GPO in all studied organs of the rats (Fig. 4).

We calculated the OSI index that shows the difference in the oxidative balance compared to a normal state that has an equilibrium between the prooxidant and antioxidant components of the oxidative balance [25]. Comparing the values of the OSI index calculated as $\mathrm{LPO} / \mathrm{SOD}+\mathrm{CAT}+\mathrm{GPx}$ ratio simplified the interpretation of the obtained results. Low values $(<1)$ of the OSI index suggest an oxidation status that is closer to oxidative balance and better antioxidant defense. The OSI index increases proportionally with the oxidative imbalance. Such an increase can be caused by either an elevation of the pro-oxidant species or a decrease of the antioxidant protection. The higher values $(>>1)$ of the OSI index suggest a greater deviation of the pro-oxidant status from the norm. The results of calculations of the OSI index are presented in Table.

As one can see in Table, Dox possesses prooxidant properties and the highest OSI was observed in heart tissue. The compound Les-3833 has a pro-oxidant effect in heart and kidney. While the compounds Les-3288 and Les-3882 demonstrated a smaller pro-oxidant action in blood and tissues, even Les-3288 had a small antioxidant effect in blood.

In a final set of experiments, we investigated possible free radical scavenging activity of the 4-thiazolidinone-based derivatives and reduced glutathione (GSH). The results presented in Fig. 5 demonstrate that the scavenging activity of the investigated substances depend significantly on both their species and duration of action. After $20 \mathrm{~min}$ of incubation, the highest anti-radical scavenging activity was demonstrated by Dox and the Les-3833 compound. However, after $24 \mathrm{~h}$ of incubation, all investigated 4-thiazolidinone derivatives increased their antioxidant activities, while the radical scavenging activity of Dox was decreased significantly.

The results of these in vitro experiments suggest that the investigated 4-thiazolidinone-based 
The oxidative stress index (OSI) for blood serum, liver, heart and kidney tissues of rats under the influence of doxorubicin and the 4-thiazolidinone derivatives

\begin{tabular}{l|l|l|l|l}
\hline & \multicolumn{1}{|c|}{ Blood } & \multicolumn{1}{c|}{ Liver } & \multicolumn{1}{c}{ Heart } & \multicolumn{1}{c}{ Kidney } \\
\hline Control & $1.00 \pm 0.00$ & $1.00 \pm 0.00$ & $1.00 \pm 0.00$ & $1.00 \pm 0.00$ \\
Doxorubicin & $3.21 \pm 0.06^{* * *}$ & $2.65 \pm 0.21^{* * *}$ & $4.41 \pm 0.18^{* * *}$ & $2.93 \pm 0.15^{* * *}$ \\
Les-3288 & $0.88 \pm 0.03$ & $1.15 \pm 0.09$ & $1.31 \pm 0.07$ & $1.64 \pm 0.11$ \\
Les-3833 & $2.09 \pm 0.12^{*}$ & $1.64 \pm 0.16$ & $2.44 \pm 0.11^{* * *}$ & $2.88 \pm 0.14^{* * *}$ \\
Les-3882 & $1.02 \pm 0.07$ & $1.27 \pm 0.23$ & $1.81 \pm 0.09$ & $1.71 \pm 0.08$ \\
\hline
\end{tabular}

$* P \leq 0.05 ; * * * P \leq 0.01$ (difference compared to control)

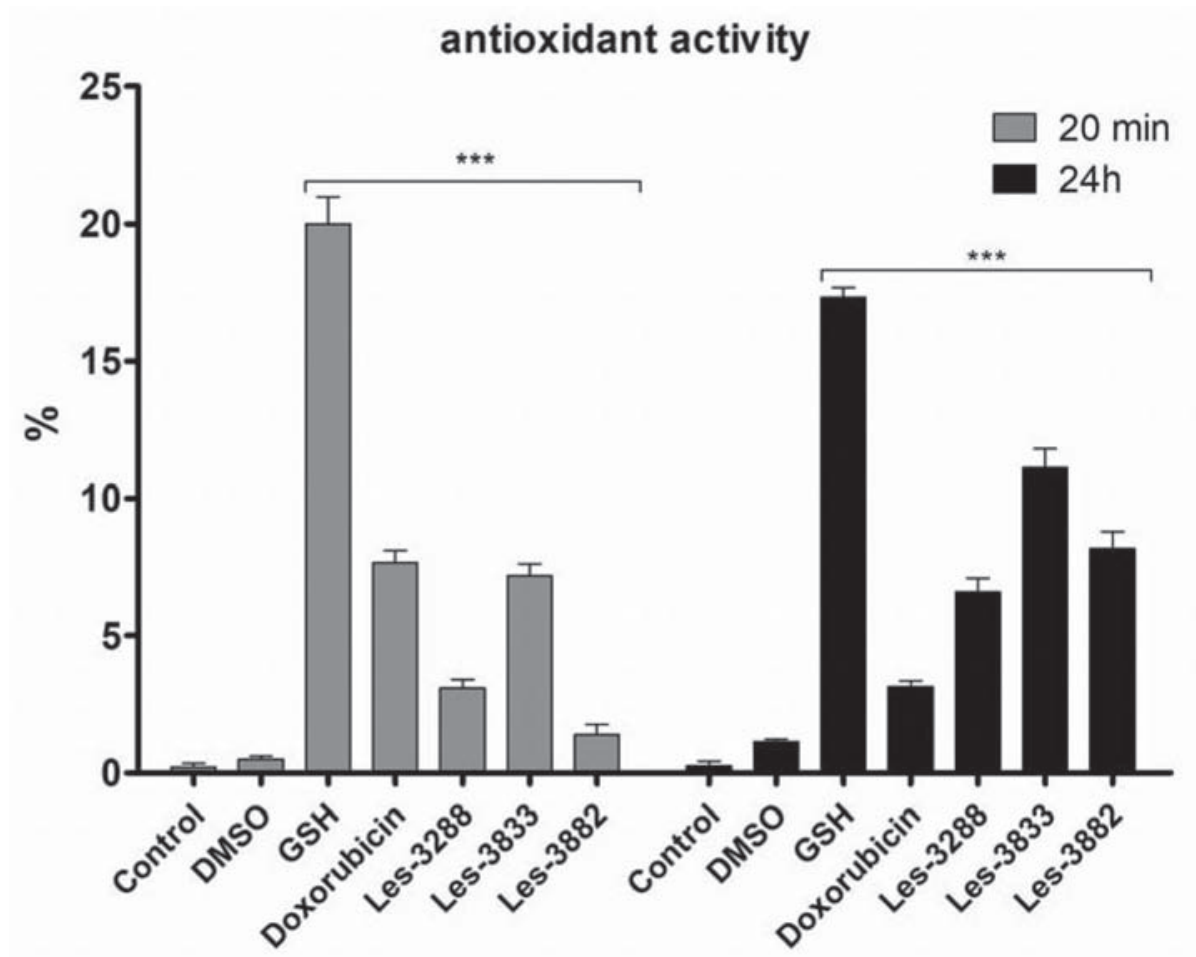

Fig. 5. Scavenging ability (\% of inhibition) in vitro of glutathione (GSH), doxorubicin and 4-thiazolidinone derivatives (Les-3288, Les-3833 and Les-3882) at 20 min and $24 \mathrm{~h} .{ }^{* * * P} \leq 0.01$

derivatives - Les-3833, Les-3288, and Les-3882 possess both antitumor activity and free radical scavenging potential that is increased with incubation time.

In a previous study, we showed that Dox and the heterocyclic 4-thiazolidinone-based derivative Les-3833 increased the level of the malonic dialdehyde in blood serum of laboratory rats, while the related derivatives Les-3288 and Les-3882 did not affect the amount of TBA-active products [26]. We also showed that 4-thiazolidinone derivatives reduced the activity of SOD and GPO in blood serum of rats, and that Les-3833 and Dox induced much more potent inhibition of the activity of these en- zymes compared to the action of other derivatives, Les-3288 and Les-3882 [26].

The results of the present study demonstrated that within 20 days the 4-thiazolidinone-based derivatives (Les-3833, Les-3288, and Les-3882), which possess antineoplastic activity in vitro and antitumor activity in vivo, also cause changes in the balance of the LPO products and the enzymatic system of the antioxidant defense in rats. The detected increase in the amount of products of LPO reactions and the depletion of the activity of enzymes of the antioxidant defense (SOD, CAT and GPO) in liver, heart and kidney tissues of rats treated with the 4-thiazolidinone derivatives are less pronounced than such 
changes induced by the known anticancer drug, Dox. One can suggest that the general toxicity of the Les3288, Les-3833 and Les-3882 compounds would be lower compared to that of Dox. This possibility was confirmed in our former studies that demonstrated much lower levels of the biochemical indicators of cardiotoxicity, hepatotoxicity, and nephrotoxicity in blood serum of rats treated with these compounds compared to rats treated with Dox [27-29]. According to the results of measuring the amount of products of the LPO reaction and the levels of decreased activity of enzymes of the antioxidant defense in three organs (liver, heart and kidney) of treated rats, the studied agents can be ranked as: Dox >> Les-3833 > Les-3288 >> Les-3882. These data are in good correspondence with our previous data that were obtained when the cytotoxicity and antitumor effect of these agents were measured in vitro and in vivo, correspondingly [18, 26, 30].

A correlation between an increased level of the indicators of LPO in the biological membranes and mitochondria and a decreased activity of enzymes of the antioxidant defense induced by the anticancer drugs in liver, heart and kidney of the laboratory animals, on the one hand, and toxic effects (cardio-, hepato , and nephrotoxicities) of these drugs in treated animals, on the other hand, have been described in other studies [27-29]. However, the novel 4-thiazolidinone derivatives used in our study induced a much lower amount of products of LPO and a much smaller decrease in the activity of enzymes of the antioxidant defense, compared to the effects of Dox - the "gold standard" of anticancer chemotherapy. Thus, the decreased general toxicity observed from using these derivatives in vivo allows their application at higher doses for treatment of tumor-bearing laboratory animals. The LPO-AOA balance in tissues and organs, specifically in liver, heart and kidney, can be used as prognostic criteria for evaluation of general toxic effects and treatment effects of applied anticancer drugs.

Here we also addressed an important issue that is rarely taken into consideration when evaluating the efficiency of the treatment action of anticancer drugs. This issue is the potential existence of inherent antioxidant properties of drugs, especially their radical scavenging activity. In this study, we described a unique capability of the 4-thiazolidinone derivatives for free radical scavenging. This capability depended on (increased with) the incubation time in vitro, while such action of Dox was decreased with the incubation time. Such a characteristic of the studied 4-thiazolidinone derivatives could explain why these compounds possess much less cardio-, hepato-, and nephrotoxicity compared with Dox, because the free radical scavenging potential of Dox was significantly lower after $24 \mathrm{~h}$ of incubation. Thus, in addition to antitumor activity, the Les3833, Les-3288, and Les-3882 compounds possess free radical scavenging potential that could be very important for inactivation of deleterious free radicals in biological systems. Scavenging of the stable DPPH radical is a widely used method for evaluating AOA [20]. DPPH is a stable free radical capable of accepting an electron or hydrogen radical to become a stable diamagnetic molecule. In this experimental model, glutathione (known antioxidant) was used as a positive control [31]. Further studies are needed to determine in more detail the biochemical mechanisms regulating AOA action of the 4-thiazolidinone derivatives, as well as to establish the pharmacological efficacy of these promising anticancer agents.

Taking into account our results from evaluation of the OSI index, one can consider that Dox and the Les-3833 derivative have a well expressed pro-oxidant effect, while the effects of the Les-3288 and Les-3882 compounds are less pro-oxidant. Of course, the free radical scavenging activity of these compounds in a simple model system consisting of the anticancer compound and the DPPH radical scavenger cannot fully reflect the pro-/anti-oxidant action of this compound in a complicated cellular system or living animal.

Conclusion. The results of our in vivo studies suggest that 4-thiazolidinone derivatives (Les-3288, Les-3833 and Les-3882) possess different anticancer potential, since only Les-3833 is capable of significant activating free radical processes and decreasing the activity of the antioxidant enzymes (SOD, CAT, and GPO) in liver, heart and kidney tissues of laboratory rats. The pro-oxidant-antioxidant balance in these tissues is an informative criterion for elucidation of the mechanism of toxic lesions induced by the anticancer drugs in animals. The results of our in vitro study of free radical scavenging activity of various 4-thiazolidinone-based derivatives and Dox suggest a weak scavenging potential for free radicals that increases with incubation time. 
Conflict of interest. Authors have completed the Unified Conflicts of Interest form at http:// ukrbiochemjournal.org/wp-content/uploads/2018/12/ coi_disclosure.pdf and declare no conflict of interest.

Acknowledgements. The study was supported by Cedars-Sinai Medical Center's International Research and Innovation in Medicine Program, the Association for Regional Cooperation in the Fields of Health, Science and Technology (RECOOP HST Association) and the participating Cedars - RECOOP Research Centers (CRRC).

\section{ПРООКСИДАНТНО- АНТИОКСИДАНТНИЙ БАЛАНС IN VITRO TA IN VIVO 3А ДIÏ ХІМІОТЕРАПЕВТИЧНИХ ЗАСОБІВ НА ОСНОВІ 4-ТІАЗОЛІДИНОНУ І3 ПРОТИПУХЛИННИМ ПОТЕНЦАЛОМ}

\section{Л. Кобилінська ${ }^{1 凶}$, О. Ключівська ${ }^{2}$, Р. Лесик ${ }^{1}$, P. Стойка ${ }^{2}$}

${ }^{1}$ Львівський національний медичний університет імені Данила Галицького, Україна;

${ }^{2}$ Інститут біології клітини НАН України; e-mail: lesya8@gmail.com

Окислювальний стрес $\epsilon$ одним iз основних механізмів, за яким протипухлинні хіміотерапевтичні засоби пошкоджують нормальні тканини та органи. У той самий час, він $€$ важливим біохімічним механізмом протипухлинної дії цих препаратів. Метою цього дослідження було визначити прооксидантно-антиоксидантний баланс in vitro та in vivo за дії нових гетероциклічних сполук із протипухлинним потенціалом на основі 4-тіазолідинону. Перевагою використання цих сполук in vivo $\epsilon$ їхня низька загальна токсичність порівняно 3 доксорубіцином. Похідні 4-тіазолідинону (Les3288, Les-3833, Les-3882) з раніше встановленою антинеопластичною активністю in vitro $\mathrm{i}$ протипухлинним ефектом in vivo синтезували, розчиняли у диметилсульфоксиді і вводили внутрішньоочеревинно щурам лінії Вістар щодня протягом 20 днів. Дози введених препаратів відповідали $10 \% \mathrm{LD}_{50}$, а саме: доксорубіцин 5,5 мг/кг, Les-3882 i Les-3833 - 10,7 мг/кг, а Les-3288 - 24,3 мг/кг. Вимірювали радикалпоглинальну активність щодо 1,1-дифеніл- 2-пікрилгідразилу (DPPH) в досліджуваних препаратів. Активність ліпопероксидації оцінювали за вмістом ТБК-активних продуктів у тканинах печінки, серця $\mathrm{i}$ нирок щурів. Активність супероксиддисмутази, каталази i глутатіонпероксидази визначали в сироватці крові і тканинах щурів. Встановлено, що введення протягом 20 днів сполук Les-3288, Les-3833 i Les-3882 порушує прооксидантно-антиоксидантний баланс у піддослідних щурів. Виявлено зростання концентрації продуктів реакцій пероксидного окислення ліпідів і виснаження ензиматичної антиоксидантної системи в тканинах печінки, серця і нирок. Сполуки Les-3288, Les-3833 i Les-3882 виявляли меншу прооксидантну дію порівняно з ефектом доксорубіцину. За результатами впливу на прооксидантноантиоксидантний баланс в обраних тканинах досліджувані сполуки можна розмістити таким чином: доксорубіцин >> Les-3833> Les-3288 >> Les-3882. Одержані результати узгоджуються 3 результатами наших нещодавніх експериментів щодо антинеопластичного ефекту цих похідних in vitro та їх протипухлинної дії in vivo. Також продемонстровано нижчу загальну токсичність ix in vivo порівняно з таким ефектом, показаним раніше для доксорубіцину.

К лючов г с слов а: похідні 4-тіазолідинону, доксорубіцин, продукти пероксидного окислення ліпідів, ензими антиоксидантного захисту, прооксидантно-антиоксидантний баланс.

\section{References}

1. Fleury C, Mignotte B, Vayssière J-C. Mitochondrial reactive oxygen species in cell death signaling. Biochimie. 2002; 84(2-3): 131141.

2. Matés JM, Sánchez-Jiménez FM. Role of reactive oxygen species in apoptosis: implications for cancer therapy. Int J Biochem Cell Biol. 2000; 32(2): 157-170.

3. Gorrini C, Harris IS, Mak TW. Modulation of oxidative stress as an anticancer strategy. Nat Rev Drug Discov. 2013; 12(12): 931-947.

4. Manda G, Nechifor MT, Neagu TM. Reactive oxygen species, cancer and anti-cancer therapies. Curr Chem Biol. 2009; 3(1): 342-366.

5. Tong L, Chuang CC, Wu S, Zuo L. Reactive oxygen species in redox cancer therapy. Cancer Lett. 2015; 367(1): 18-25. 
6. Udensi UK, Tchounwou PB. Dual effect of oxidative stress on leukemia cancer induction and treatment. J Exp Clin Cancer Res. 2014; 33: 106.

7. Lin MT, Beal MF. Mitochondrial dysfunction and oxidative stress in neurodegenerative diseases. Nature. 2006; 443(7113): 787-795.

8. Ayala A, Muñoz MF, Argüelles S. Lipid peroxidation: production, metabolism, and signaling mechanisms of malondialdehyde and 4-hydroxy-2-nonenal. Oxid Med Cell Longev. 2014; 2014: 360438.

9. Watson J. Oxidants, antioxidants and the current incurability of metastatic cancers. Open Biol. 2013; 3(1): 120144.

10. Kobylinska LI, Tymochko MF. The role of prooxidant-antioxidant balance in the adaptational reactions of organism. Exp Clin Physiol Biochem. 2000; 4: 52-58. (In Ukrainian).

11. Tymochko MPh, Kobylinska LI. Free radical reactions and their metabolic role. Med Chem. 1999; 1(1): 19-25. (In Ukrainian).

12. Stefanov OV. Preclinical Studies of Medicines. Methodological Recommendations. 2001. 527 p. (In Ukrainian).

13. Ali R, Mirza Z, Ashraf GM, Kamal MA, Ansari SA, Damanhouri GA, Abuzenadah AM, Chaudhary AG, Sheikh IA. New anticancer agents: recent developments in tumor therapy. Anticancer Res. 2012; 32(7): 2999-3005.

14. Kaminskyy D, Kryshchyshyn A, Lesyk R. 5-Ene-4-thiazolidinones - An efficient tool in medicinal chemistry. Eur J Med Chem. 2017; 140: 542-594.

15. Havrylyuk D, Roman O, Lesyk R. Synthetic approaches, structure activity relationship and biological applications for pharmacologically attractive pyrazole/pyrazoline-thiazolidinebased hybrids. Eur J Med Chem. 2016; 113: 145166.

16. Lesyk RB, Zimenkovsky BS, Kaminskyy DV, Kryshchyshyn AP, Havrylyuk DYa, Atamanyuk DV, Subtel'na IYu, Khylyuk DV. Thiazolidinone motif in anticancer drug discovery. Experience of DH LNMU medicinal chemistry scientific group. Biopolym Cell. 2011; 27(2): 107-117.

17. Havrylyuk D, Zimenkovsky B, Vasylenko O, Zaprutko L, Gzella A, Lesyk R. Synthesis of novel thiazolone-based compounds containing pyrazoline moiety and evaluation of their anticancer activity. Eur J Med Chem. 2009; 44(4): 1396-1404.

18. Kobylinska L, Skorohyd N, Klyuchivska O, Mitina N, Zaichenko A, Lesyk R, Zimenkovsky B, Stoika R. Increased antitumor efficiency and reduced negative side effects in laboratory mice of 4-thiazolidinone derivatives in complexes with PEG-containing polymeric nanocarrier. Biopolym Cell. 2018; 34(4): 313-328.

19. Havrylyuk D, Zimenkovsky B, Vasylenko O, Gzella A, Lesyk R. Synthesis of new 4-thiazolidinone-, pyrazoline-, and isatin-based conjugates with promising antitumor activity. J Med Chem. 2012; 55(20): 8630-8641.

20. Asatiani MD, Elisashvili VI, Wasser SP, Reznick AZ, Nevo E. Free-radical scavenging activity of submerged mycelium extracts from higher basidiomycetes mushrooms. Biosci Biotechnol Biochem. 2007; 71(12): 3090-3092.

21. Timirbulatov RA, Seleznev EI. Method for increasing the intensity of free radical oxidation of lipid-containing components of the blood and its diagnostic significance. Lab Delo. 1981; (4): 209-211. (In Russian).

22. Kostyuk VA, Potapovich AI, Kovaleva ZhV. A simple and sensitive method of determination of superoxide dismutase activity based on the reaction of quercetin oxidation. Vopr Med Khim. 1990; 36(2): 88-91. (In Russian).

23. Korolyuk MA, Ivanova LI, Mayorova IG, Tokarev VE. A method of determining catalase activity. Lab Delo. 1988; (1): 16-19. (In Russian).

24. Moin VM. A simple and specific method for determining glutathione peroxidase activity in erythrocytes. Lab Delo. 1986; (12): 724-727. (In Russian).

25. Ruas CB, Carvalho Cdos S, de Araújo HS, Espíndola EL, Fernandes MN. Oxidative stress biomarkers of exposure in the blood of cichlid species from a metal-contaminated river. Ecotoxicol Environ Saf. 2008; 71(1): 86-93.

26. Kobylinska LI, Boiko NM, Panchuk RR, Grytsyna II, Klyuchivska OY, Biletska LP, Lesyk RB, Zimenkovsky BS, Stoika RS. Putative anticancer potential of novel 4-thiazolidinone derivatives: cytotoxicity toward rat C6 glioma in vitro and correlation of general toxicity with the balance of free radical oxidation in rats. Croat Med J. 2016; 57(2): 151-163.

27. Kobylinska LI, Havrylyuk DYa, Ryabtseva AO, Mitina NE, Zaichenko OS, Zimenkovsky BS, 
Stoika RS. Study of rat blood serum biochemical indicators of cardiotoxic action of novel 4-thiazolidone derivatives and doxorubicin in complexes with polyethylenglycol-containing polymeric carrier. Ukr Biochem J. 2014; 86(6): 84-95. (In Ukrainian).

28. Kobylinska LI, Havrylyuk DYa, Ryabtseva AO, Mitina NE, Zaichenko OS, Lesyk RB, Zimenkovsky BS, Stoika RS. Biochemical indicators of hepatotoxicity in blood serum of rats under the effect of novel 4-thiazolidinone derivatives and doxorubicin and their complexes with polyethyleneglycol-containing nanoscale polymeric carrier. Ukr Biochem J. 2015; 87(2): 122-132.

29. Kobylinska LI, Havrylyuk DY, Mitina NE, Zaichenko AS, Lesyk RB, Zimenkovsky BS,
Stoika RS. Biochemical indicators of nephrotoxicity in blood serum of rats treated with novel 4-thiazolidinone derivatives or their complexes with polyethylene glycol-containing nanoscale polymeric carrier. $U k r$ Biochem $J$. 2016; 88(1): 51-60.

30. Kobylinska L, Lesyk R, Stoyka R, Zimenkovsky B. Search for imbalance mechanisms of the metabolic indicators and natural detoxification at the action of new 4-thiazolidinone derivatives possessing antineoplastic activity. Exp Clin Physiol Biochem. 2016; 75(3): 24-34.

31. Gaucher C, Boudier A, Bonetti J, Clarot I, Leroy P, Parent M. Glutathione: antioxidant properties dedicated to nanotechnologies. Antioxidants (Basel). 2018; 7(5). pii: E62. 